\title{
Stress Analysis of Composite Materials Used for Yacht Production Through Solid Work Simulation
}

\section{Mirela $\mathrm{KOCl}$}

Phd. Candidate, Polytechnic University of Tirana

\begin{abstract}
In recent years, considerable progress has been made in understanding the characteristic of composite materials and their tailored structures in the marine environment. Processing and production sectors also have received more attention resulting in the potential for the construction of complex, large assemblies capable of withstanding heavy loads. However, the key challenges involved in employing composites for marine applications include the need for optimization of capital expenditure and operating costs of boats, ships and other marine artifact's constructed using composites. Materials science and composite technology are advancing rapidly, and new composites such as epoxy mixtures including the application of carbon nano tubes are becoming more popular with ever growing concern for high performance marine structures. Indeed, lightness, ease of production, durability and strength enable composites to play a vital role in marine applications. As the Marine sector continues to look at improving efficiency and reducing overall costs, Composite materials will play a huge part in the future of Marine construction. The paper is focused to the static linear simulation of elastic bodies using Solid Works Simulation. Stresses analyses have been developed in the static analyze which provide tools for the linear stress analysis of parts and assemblies loaded by static loads, taking in consideration for the analyze the most stressed part of the bottom, board and desk of the yachts
\end{abstract}

Keywords: Static analyze, stress, composite materials, optimization, marine sector, leisure yachts.

\section{Introduction}

The advantage of material properties and flexibility of choosing material have made composite materials a primary preference for structural application. Unlike isotropic materials, the parametric study of composite beams for optimized design is complicated due to high number of parameters involved in designing like lay-up sequence, and layer configuration. Moreover, the limitations of FEA techniques in designing have created a need for an analytical closed-form solution for stress analysis of laminated composite beams.

The objective of this study focuses on the development of an analytical method for stress analysis of composite beam. This method includes the structural response due to unsymmetrical and/or unbalanced of laminate as well as unsymmetrical Ibeam cross-section. These structural characteristics are often ignored in the most published studies.

Analytical closed-form expressions for the Von misses indicator, stress and strain coefficient, and URES parameter are generated from the different simulation with different composite materials for the three main parts of the ship, hull, board and deck using Alfa Solid Work commercial soft.

\section{Coordinate System for Lamina and Laminates}

A laminate is made up of perfectly bonded layers of lamina with different fiber orientation to represent an integrated structural component. In most practical applications of composite material, the laminates are considered as thin and loaded along the plane of laminates. A thin orthotropic unidirectional lamina as depicted in Figure 2.1 has fiber orientation along the 1-direction and the direction transverse to the fiber along the 2-direction. The $x-y$ coordinates represent the global coordinate system for the lamina. 

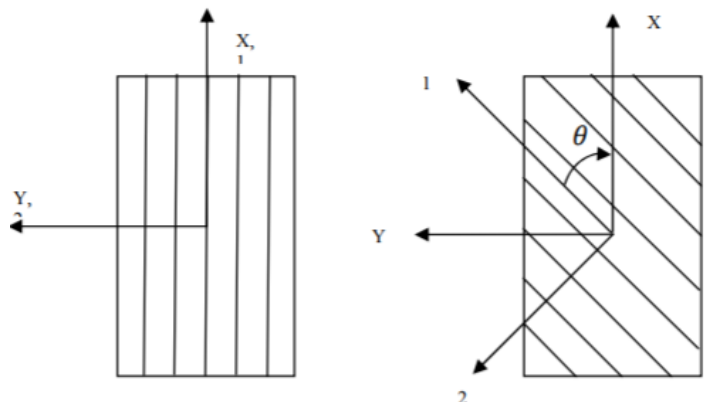

Figure 2.1 Coordinates of Lamina.

7

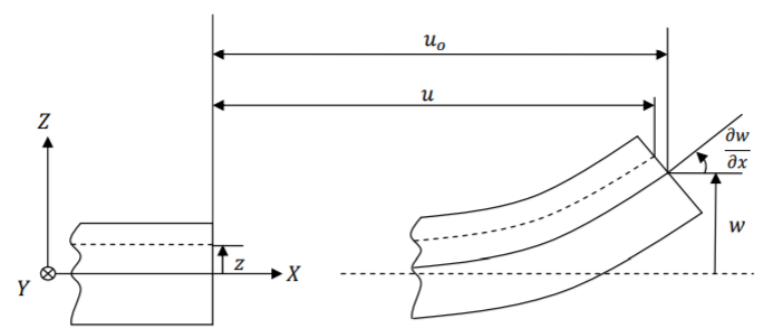

Figure 2.2 Laminate Section Before and After Deformation. [14]

Since each lamina has individual coordinate system, the strain-displacement relation for a laminate is represented easily along a convenient common axis in the reference plane. The reference plane is selected along the mid-plane of the laminate for simplicity. Moreover, the laminate are assumed to be bending without slipping over each other and the cross-section of the laminate remains unwrapped. Transverse shear strain are also considered to be negligible. Considering these assumptions the in-plane displacement at any point with coordinate $z$ can be written as (see Figure 2.2)

$$
u=u_{\sigma}-z \frac{\partial w}{\partial x}
$$

\section{Narrow and Wide Beams}

The structural response of the beam is dependent on the ratio of the width to height of the beam cross section. For a beam subjected to bending, the induced lateral curvature is insignificant if the width to height ratio is large. This kind of beam is so-called "wide beam". 16 Conversely, if the width to height ratio of the cross section is small, the beam is called "narrow beam". For this case, the lateral curvature is induced due to the effect of Poisson's ratio. As the result, lateral moment is zero. 


$\begin{array}{lll}\text { Wide beam, } & M_{y} \neq 0 & K_{y}=0 \\ \text { Narrow beam, } & M_{y}=0 & K_{y} \neq 0\end{array}$

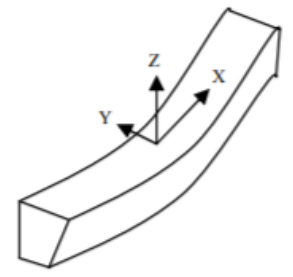

(a)

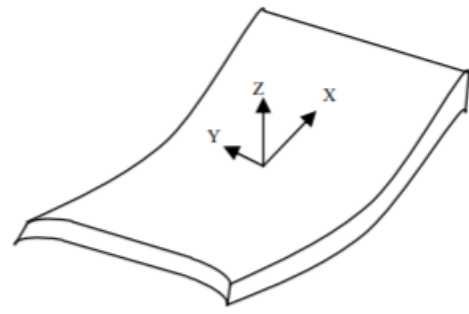

(b)

Figure 2.4 (a) Narrow and (b) Wide Beams under Bending.

\section{Stress and Strain in Laminates}

Stress and Strain are the two building blocks of structural analysis. They are what we use to understand where a component is in relationship to material failure, sharing a close relationship. So close that sometimes their definitions both contain each other making it difficult to understand them individually. What they have in common is:

Stress and Strain are both responses to applied loads on a structure.

Stress and Strain are both measurements to determine material failure criteria and behavior

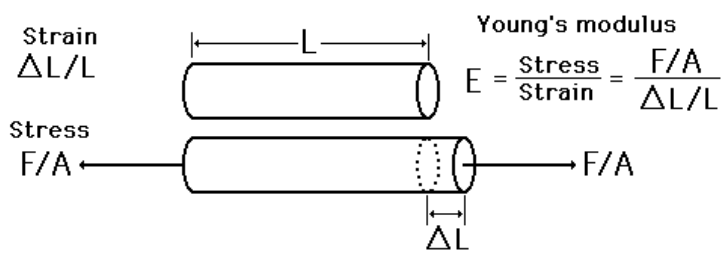

The methodology of the study include the stress analyzing of the most loaded panels for hull, board and decks for a small composite vessel with $5.5 \mathrm{~m}$ length based on the respective designs.

\section{Panel Analyses Based on ISO 2008 Standard}

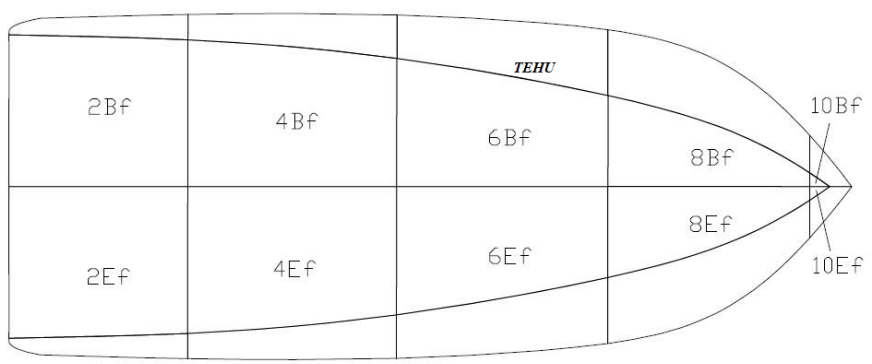




\section{Vessel's parameters}

$\mathrm{LOA}=5,457 \mathrm{~m}$

$\mathrm{LWL}=5,040 \mathrm{~m}$

$B W L=1,912 \mathrm{~m}$

$B \max =2,243 \mathrm{~m}$

$D W L=0,357 \mathrm{~m}$

$\Delta=756,652$

Navigation speed $V=40$ nyje.

\section{Hull panels}

\begin{tabular}{|l|l|l|l|l|l|}
\cline { 2 - 6 } \multicolumn{1}{c|}{} & \multicolumn{4}{l|}{ Dimensions for hull panel (mm) } \\
\cline { 2 - 6 } \multicolumn{1}{c|}{ Panel } \\
\cline { 2 - 6 } \multicolumn{1}{c|}{} & 2 & 4 & 6 & 8 & 10 \\
\hline L & 1160 & 1361 & 1397 & 1419 & 290 \\
\hline B & 1041 & 960 & 802 & 290 & 257 \\
\hline
\end{tabular}

\begin{tabular}{|l|l|l|l|l|l|}
\cline { 2 - 6 } \multicolumn{1}{c|}{} & \multicolumn{4}{|l|}{ Panel } \\
\cline { 2 - 6 } \multicolumn{1}{c|}{} & $\mathbf{2}$ & $\mathbf{4}$ & $\mathbf{6}$ & $\mathbf{8}$ & $\mathbf{1 0}$ \\
\hline Pressure in the panel Pbm & 40,21208 & 39,25379 & 30,515535 & 42,8477 & 73,93265 \\
\hline
\end{tabular}

The panel 4 is the most stressed panel, so every simulation on Solid Work will be done for this panel taking in consideration two types of composites composite with plains and sandwich composites.

\section{Simulation oh hull panel in Solid Work Software}

The simulation of panel 4 for hull has been done for 6 composite materials respectively: Composite EPOXY-Rubber, Eglass-EPOXY, PVC - Natural Rubber, Resin-Rubber, Polyester resin - Natural Rubber, Custom plastic- Rubber. The composite was composed from 16 plains of the above mentioned materials symmetric ones.

Simulation process start with panel design that can be done on CAD and transported on Solid Work or designed directly there.

\section{Simulation of EPOXY- RUBBER panel}

Geometric modeling of the panel 4 for the hull of small vessel $5.5 \mathrm{~m}$ length

$$
\text { 之 }
$$

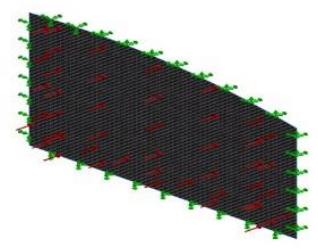

New static study, define the type of composite, entered the parameters for it, thickness for every plain, angle, volume, density of material, mass and weight. It has been chosen the composite with 16 combined plains in a symmetric way. 


\begin{tabular}{|c|c|c|c|c|c|c|c|c|}
\hline & $\begin{array}{l}\text { Tota } \\
\text { symn }\end{array}$ & $\begin{array}{l}\text { err of Plies: } \\
\text { Yes }\end{array}$ & & & & & & \\
\hline & Ply & $\begin{array}{l}\text { Thicknes } \\
\text { s(mm) }\end{array}$ & $\begin{array}{l}\text { Angle(de } \\
\text { g) }\end{array}$ & $\begin{array}{l}\text { Area(m } \\
\text {-2) }\end{array}$ & $\begin{array}{l}\text { Volume } \\
(\mathrm{m}-3)\end{array}$ & $\begin{array}{l}\text { Density ( } \\
\mathrm{kg} / \mathrm{m}^{-3} \text { ) }\end{array}$ & $\begin{array}{l}\text { Masst } \\
\text { kg) }\end{array}$ & $\begin{array}{l}\text { Werght } \\
\text { (N) }\end{array}$ \\
\hline & 1 & 0.7 & $\circ$ & 1.26638 & $\begin{array}{l}0.00088 .8 \\
6464\end{array}$ & 1100 & $\begin{array}{l}0.975 \\
11\end{array}$ & $\begin{array}{l}9.5560 \\
8\end{array}$ \\
\hline & 2 & 0.58 & 45 & 1.26638 & $\begin{array}{l}0.00073 \\
4498\end{array}$ & 1000 & $\begin{array}{l}0.734 \\
498\end{array}$ & \begin{tabular}{|l|}
7.1980 \\
8
\end{tabular} \\
\hline & 3 & 1.05 & -45 & 1.26638 & $\begin{array}{l}0.00132 \\
97\end{array}$ & 1100 & $\begin{array}{l}1,462 \\
67\end{array}$ & \begin{tabular}{|l|}
14.334 \\
1.3 \\
\end{tabular} \\
\hline & 4 & 0.64 & $\circ$ & 1.26638 & $\begin{array}{l}0.000811 \\
0481\end{array}$ & 1000 & $\begin{array}{l}0.810 \\
481\end{array}$ & \begin{tabular}{|l|}
7.9427 \\
1
\end{tabular} \\
\hline & 5 & 1.05 & 45 & 1.26638 & $\begin{array}{l}0.00132 \\
97\end{array}$ & 1100 & $\begin{array}{l}1.462 \\
67\end{array}$ & \begin{tabular}{|l|}
14.334 \\
$1^{4}$ \\
\end{tabular} \\
\hline Surtace-Plane1 & 6 & 0.77 & -45 & 1.26638 & $\begin{array}{l}0.00097 \\
511\end{array}$ & 1000 & $\begin{array}{l}0.975 \\
11\end{array}$ & \begin{tabular}{|l|}
9.5560 \\
8 \\
\end{tabular} \\
\hline & 7 & 1.05 & $\circ$ & 1.26638 & $\begin{array}{l}0.00132 \\
97\end{array}$ & 1100 & $\begin{array}{l}1.462 \\
67\end{array}$ & \begin{tabular}{|l|}
14.334 \\
$1^{4}$ \\
\end{tabular} \\
\hline & 8 & 1.03 & 45 & 1.26638 & $\begin{array}{l}0.00130 \\
437\end{array}$ & 1000 & $\begin{array}{l}1,304 \\
37\end{array}$ & $\begin{array}{l}12.782 \\
8\end{array}$ \\
\hline & 9 & 1.03 & 45 & 1.26638 & $\begin{array}{l}0.00130 \\
437\end{array}$ & 1000 & $\begin{array}{l}1.304 \\
37^{3}\end{array}$ & \begin{tabular}{|l|}
12.782 \\
$8^{2}$
\end{tabular} \\
\hline 2 & 10 & 1.05 & $\circ$ & 1.26638 & $\begin{array}{l}0.00132 \\
97\end{array}$ & 1100 & $\begin{array}{l}1,462 \\
67\end{array}$ & \begin{tabular}{|l|}
14.334 \\
1
\end{tabular} \\
\hline & 11 & 0.77 & -45 & 1.26638 & $\begin{array}{l}0.00097 \\
511 \\
\end{array}$ & 1000 & $\begin{array}{l}0.975 \\
11\end{array}$ & \begin{tabular}{|l|}
9.5560 \\
8 \\
\end{tabular} \\
\hline & 12 & 1.05 & 45 & 1.26638 & $\begin{array}{l}0.00132 \\
97\end{array}$ & 1100 & $\begin{array}{l}1.462 \\
67\end{array}$ & \begin{tabular}{|l|l|}
14.334 \\
$1^{1}$
\end{tabular} \\
\hline & 13 & 0.64 & $\circ$ & 1.26638 & $\begin{array}{l}0.00081 \\
0481\end{array}$ & 1000 & $\begin{array}{l}0.810 \\
481\end{array}$ & \begin{tabular}{|l|}
7.9427 \\
1
\end{tabular} \\
\hline & 14 & 1.05 & -45 & 1.26638 & $\begin{array}{l}0.00132 \\
97\end{array}$ & 1100 & $\begin{array}{l}1.462 \\
67\end{array}$ & \begin{tabular}{|l|}
14.334 \\
1
\end{tabular} \\
\hline & 15 & 0.58 & 45 & 1.26638 & $\begin{array}{l}0.00073 \\
4498\end{array}$ & 1000 & $\begin{array}{l}0.734 \\
498\end{array}$ & $\begin{array}{l}7.1980 \\
8\end{array}$ \\
\hline & 16 & 0.7 & $\circ$ & 1.26638 & $\begin{array}{l}0.0008 .8 \\
6464\end{array}$ & 1100 & $\begin{array}{l}0.975 \\
11 \\
\end{array}$ & \begin{tabular}{|l|}
9.5560 \\
8
\end{tabular} \\
\hline & $\begin{array}{l}\text { Dod } \\
\text { rub } \\
\text { Dat }\end{array}$ & $\begin{array}{l}\text { me: } c: \\
\text { 1: sep }\end{array}$ & $\begin{array}{l}\text { :ersLAULE } \\
20: 42: 31\end{array}$ & 17 & eli 4 & i stuc & 1 EPOX & \\
\hline
\end{tabular}

Defining the materials selected from the library of Solid Work software. In our case has been chosen Epoxy Unfilled and Rubber. The model type was chosen Linear elastic Orthotropic with the respective tensile strength in $\mathrm{x}$, compressive strength, elastic modulus and Poison's Ratio according to the material.

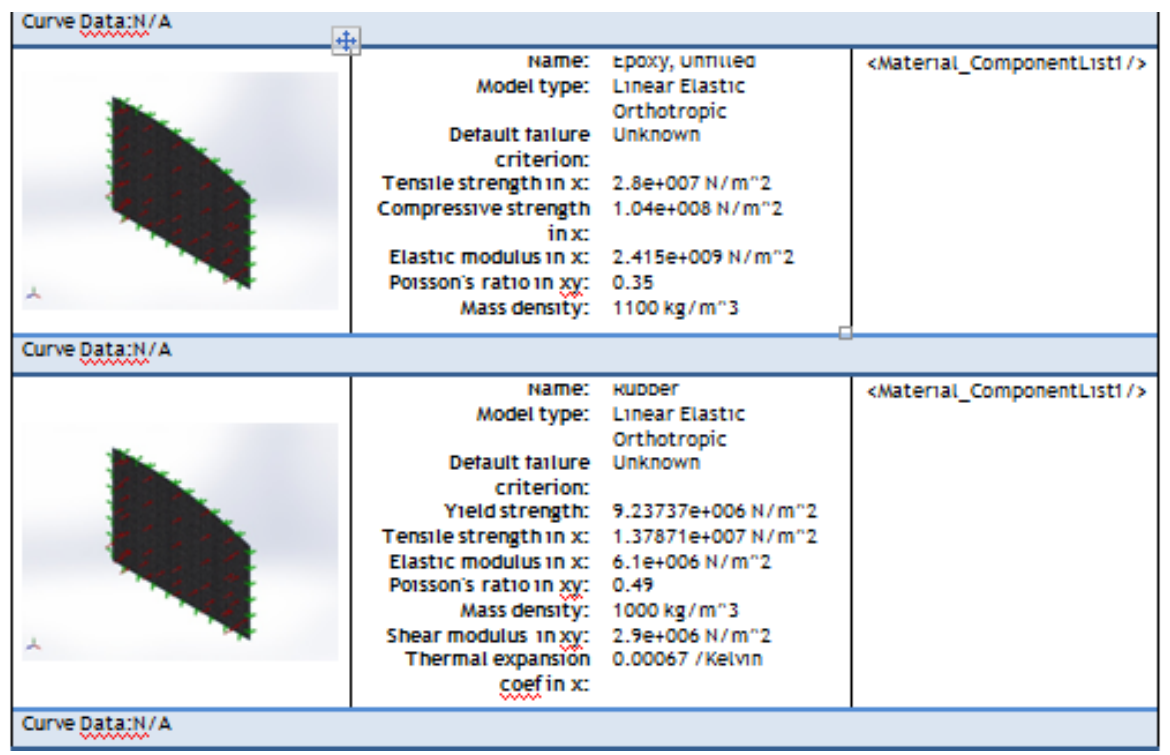

Fixture and Loads of the plan has been done in all directions taking in consideration that we are developing a static study. The value of the maximal pressure on the panel 4 is the load applied in the panel in each piece of it. 


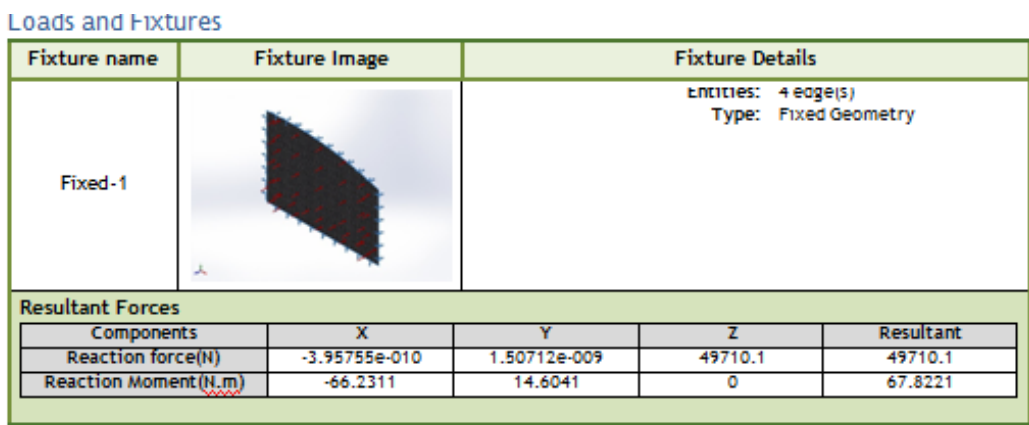

\begin{tabular}{|l|c|c|}
\hline Load name & Load Image & Load Details \\
\hline & & tentitles: 1 race(s) \\
& Type: Normal to selected tace \\
& Value: 39253.8 \\
Pressure-1 & Unts: N/m"2 \\
& & Phase Angle: 0 \\
& Units: deg \\
& & \\
\hline
\end{tabular}

Mesh and run the study is the final process, before the software generate the report. Report results create the possibility to receive the appropriate data that can help for the definition of the appropriate composite material which can satisfy the necessary parameters for durability and weight.
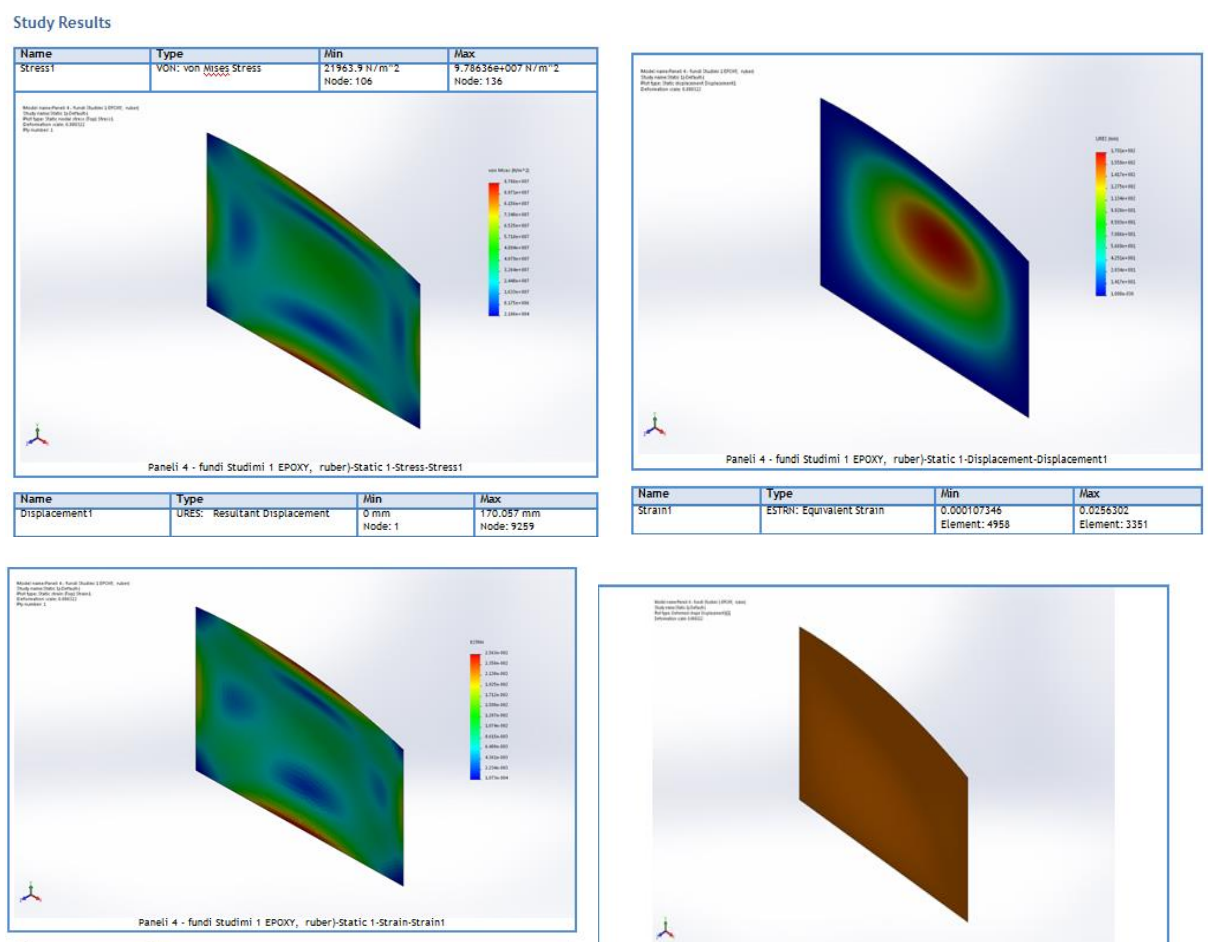

\begin{tabular}{|l|l|}
\hline Name & Type \\
\hline Oisplicementritis & Oetormecoshape \\
\hline
\end{tabular}

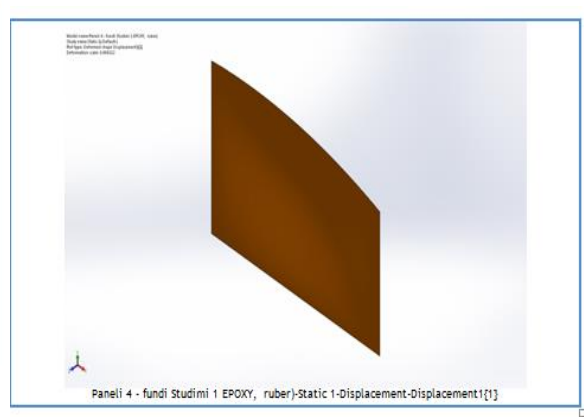

Based on the same methodology has been generated from the software the respective reports for every composite applied. 
The table 1. below shows the most important parameters that can be used to analyze which composite material is more appropriate for the yacht hull construction.

\begin{tabular}{|l|l|l|l|l|l|l|}
\hline The material & $\begin{array}{l}\text { Material } \\
\text { mass in }(\mathrm{kg})\end{array}$ & Thickness $(\mathrm{mm})$ & $\begin{array}{l}\text { Von misses } \\
\text { stress N/m2 }\end{array}$ & URES (mm) & ESTRN & $\begin{array}{l}\text { Deformation } \\
\text { scale }\end{array}$ \\
\hline $\begin{array}{l}\text { Epoxy unfilled - } \\
\text { rubber }\end{array}$ & 18.375 & 13.74 & $9.786 \mathrm{e}+007$ & 1.701 & 2.563 & 0.8 \\
\hline $\begin{array}{l}\text { Resin-natural } \\
\text { rubber }\end{array}$ & 17.59 & 13.74 & $1.011 \mathrm{e}+007$ & $\mathbf{2 . 1 2 5}$ & 3.14 & 0.64 \\
\hline $\begin{array}{l}\text { E-glass - epoxy } \\
\text { (sandwich) }\end{array}$ & 39.9 & 13.76 & $9.64 \mathrm{e}+007$ & 3.688 & 5.599 & 5.52 \\
\hline $\begin{array}{l}\text { PVC - Natural } \\
\text { rubber }\end{array}$ & 18.75 & 13.74 & $9.786 \mathrm{e}+007$ & 1.701 & 2.563 & 0.8 \\
\hline $\begin{array}{l}\text { Polyester resin - } \\
\text { Natural Rubber }\end{array}$ & 18.65 & 13.74 & $1.14 \mathrm{e}+007$ & 2.463 & 3.711 & 5.52 \\
\hline $\begin{array}{l}\text { Common Plastic - } \\
\text { Rubber }\end{array}$ & 18.4 & 13.76 & $9.599 \mathrm{e}+007$ & 1.691 & 2.39 & 0.8 \\
\hline
\end{tabular}

The same simulation methodology is going to be used for the most stressed panel of board $\mathrm{nr} 3$ and the panel of deck nr 5 in the below designs respective design No1 for the board (panel 3) and design No 2,3 for the deck (panel 5)
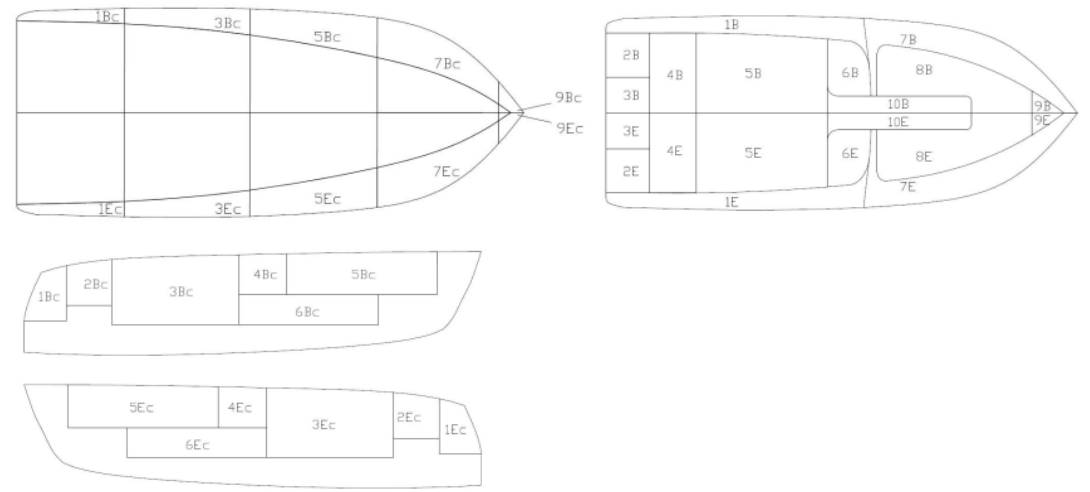

Based on the same methodology has been selected between six different composite materials the composite EPOXYRubber as the most appropriate for the construction of the panel 5 for the deck and the same material for the construction of panel 3 of the board.

\section{Conclusions:}

Composite materials are the most appropriate materials for the construction of yachts and small boats due to the very good parameters in weight and durability.

Solid work simulation static stress analyze offers the possibility to apply different composition of the materials and select the most appropriate material based on weight, tensile stress and deformation.

The composite EPOXY - Rubber is the most appropriate material for the construction of board and deck panels, instead of other composites taking in consideration the static analyze

Polyester resin - Rubber Composite is the most appropriate composite to be recommended to the constructors of yachts for the hull construction.

Sandwich materials are not recommended for the hull construction due to the very high weight they have. 